Pacific Journal of Mathematics

ABSOLUTE EXTENSOR SPACES: A CORRECTION AND AN 


\section{ABSOLUTE EXTENSOR SPACES: A CORRECTION AND AN ANSWER}

\section{CARLOS R. Borges}

This paper has a two-fold purpose: The first is to make a minor correction in the proof of a result of ours, which states that any hyperconnected space is an AE (stratifiable) and the second is to give an affirmative answer to a question of Vaughan: Does Dugundji's Extension Theorem remain valid for linearly stratifiable spaces?

1. A correction. As it stands, the proof of Theorem 4.1 of [1] is incorrect, because the function $g$ is not well-defined. (Obviously, for each $x \in X-A$, there is some implicit order in the selection of $p_{V_{1}}, \cdots, p_{V_{n}}$ such that $V_{1}, \cdots, V_{n}$ are the only elements $V \in \mathscr{Y}$ for which $p_{V}(x) \neq 0$. However, no explicit mention of it is made.) The proof is easily corrected however, by taking the following three steps:

1. Assign a total order " $\leqq$ " to $\mathscr{Y}$ :

2. Add to the function $g$ the sentence "and $V_{1} \leqq V_{2} \leqq \cdots \leqq V_{n}$."

3. On page 615 of [1], replace

(a) "say $V_{1}, \cdots, V_{m}, \cdots, V_{m+k}$ " by "say $W_{1}, \cdots, W_{m+k}$ such that $W_{1} \leqq \cdots \leqq W_{m+k} "$

(b) “ $\left(p_{V_{1}}(x), \cdots, p_{V_{m}}(x), 0, \cdots, 0\right) \in P_{m+k-1}$ ” by

$$
\text { “( } \left.p_{W_{1}}(x), \cdots, p_{W_{m+k}}(x)\right) \in P_{m+k-1} ",
$$

(c) “ $t \rightarrow\left(h_{m+k}\left(f\left(a_{V_{2}}\right), \cdots, f\left(a_{V_{m+k}}\right), t\right)\right.$ " by

$$
\text { “ } t \rightarrow h_{m+k}\left(f\left(a_{W_{1}}\right), \cdots, f\left(a_{W_{m+k}}\right), t\right),,
$$

(d) “ $p(y)=\left(p_{V_{1}}(y), \cdots, p_{V_{m-k}}(y)\right)$ " by

$$
\text { “p }(y)=\left(p_{W_{1}}(y), \cdots, p_{W_{m+l}}(y)\right) " .
$$

2. An answer. Recently, Vaughan [7] asked if Dugundji's Extension Theorem (Theorem 4.1 of [6]) remains valid for linearly stratifiable spaces. ${ }^{1}$ It turns out that the answer is affirmative and it requires little effort. Indeed, all our generalizations of Dugundji's Extension Theorem remain valid for linearly stratifiable spaces.

Theorem 2.1. [2; Theorem 4.1], [3; Theorem 3.1], [4; Theorem

${ }^{1}$ A $T_{1}$-space $X$ is said to be linearly stratifiable provided there exists some infinite cardinal number $\alpha$ such that to each open $U \subset X$ one can assign a family $\left\{U_{\beta}\right\}_{\beta<\alpha}$ of open subsets of $X$ such that (a) $U_{\beta}^{-} \subset U$ for all $\beta<\alpha$, (b) $U\left\{_{\beta} \mid \beta<\alpha\right\}=U$, (c) $U_{\beta} \subset U_{\beta}$ whenever $U \subset V$, (d) $U_{\gamma} \subset U_{\beta}$ whenever $\gamma<\beta<\alpha$. 
5.2] and [5; Theorems 4.1 and 4.2] remain valid for linearly stratifiable spaces.

Proof. All we need do is the following two alterations in Definition 4.1 of [2] and the proof of Theorem 4.1 of [2]. (The same alterations apply to the proofs of the other results):

1. In Definition 4.1 of [7] replace the word "integer" by the word "ordinal".

2. Replace the sentence "Note that $m(x)<\infty$ and, in fact, $m(x)<$ $n(W, x)$ " by the sentence "Note that $m(x)<n(W, x)$ " on the fourth line of the proof of Theorem 4.3 of [2]. The same applies to the other proofs.

\section{REFERENCES}

1. C. R. Borges, A study of absolute extensor spaces, Pacific J. Math., 31 (1969), 609-617.

2. — On stratifiable spaces, Pacific J. Math., 17 (1966), 1-16.

3. — Continuous extensions, Proc. Amer. Math. Soc., 18 (1967), 874-878.

4. — A study of multivalued functions, Pacific J. Math., 23 (1967), 451-461.

5. — A study of absolute extensor spaces, Pacific J. Math., 31 (1969), 609-617.

6. J. Dugundji, An extension of Tietze's theorem, Pacific J. Math., 1 (1951), 353-367.

7. J. E. Vaughan, Linearly stratifiable spaces, Pacific J. Math., 43 (1972), 254-266.

Received May 23, 1972.

UNIVERSITY OF CALIFORNIA, DAVIS 


\section{PACIFIC JOURNAL OF MATHEMATICS}

\section{EDITORS}

RICHARD ARENS (Managing Editor) University of California

Los Angeles, California 90024

R. A. BeaUmont

University of Washington Seattle, Washington 98105
J. DUGUNDJI*

Department of Mathematics University of Southern California Los Angeles, California 90007

D. Gilbarg and J. Milgram Stanford University

Stanford, California 94305

\section{ASSOCIATE EDITORS}

E. F. BECKENBACH

B. H. NeUmanN

F. WOLF

K. YoSHIDA

\section{SUPPORTING INSTITUTIONS}

\section{UNIVERSITY OF BRITISH COLUMBIA CALIFORNIA INSTITUTE OF TECHNOLOGY UNIVERSITY OF CA.LIFORNIA MONTANA STATE UNIVERSITY UNIVERSITY OF NEVADA NEW MEXICO STATE UNIVERSITY OREGON STATE UNIVERSITY UNIVERSITY OF OREGON OSAKA UNIVERSITY}

UNIVERSITY OF SOUTHERN CALIFORNIA STANFORD UNIVERSITY UNIVERSITY OF TOKYO UNIVERSITY OF UTAH WASHINGTON STATE UNIVERSITY UNIVERSITY OF WASHINGTON AMERICAN MATHEMATICAL SOCIETY NAVAL WEAPONS CENTER

* C. R. DePrima California Institute of Technology, Pasadena, CA 91109, will replace J. Dugundji until August 1974. 


\section{Pacific Journal of Mathematics}

\section{Vol. 50, No. $1 \quad$ September, 1974}

Gail Atneosen, Sierpinski curves in finite 2-complexes.............. 1

Bruce Alan Barnes, Representations of $B^{*}$-algebras on Banach spaces .... 7

George Benke, On the hypergroup structure of central $\Lambda(p)$ sets ....... 19

Carlos R. Borges, Absolute extensor spaces: a correction and an

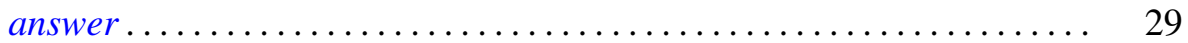

Tim G. Brook, Local limits and tripleability .................. 31

Philip Throop Church and James Timourian, Real analytic open maps .... 37

Timothy V. Fossum, The center of a simple algebra ............... 43

Richard Freiman, Homeomorphisms of long circles without periodic

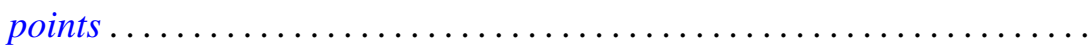

B. E. Fullbright, Intersectional properties of certain families of compact

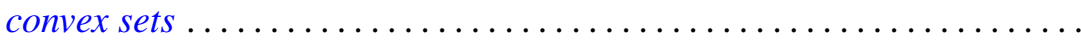

Harvey Charles Greenwald, Lipschitz spaces on the surface of the unit

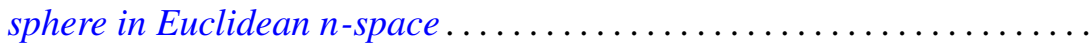

Herbert Paul Halpern, Open projections and Borel structures for

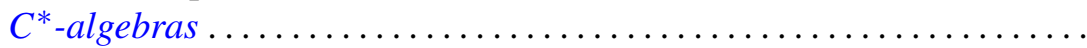

Frederic Timothy Howard, The numer of multinomial coefficients divisible

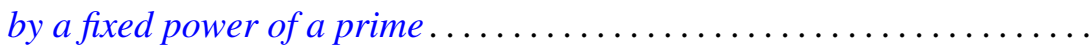

Lawrence Stanislaus Husch, Jr. and Ping-Fun Lam, Homeomorphisms of manifolds with zero-dimensional sets of nonwandering points........ 109

Joseph Edmund Kist, Two characterizations of commutative Baer rings ...

Lynn McLinden, An extension of Fenchel's duality theorem to saddle functions and dual minimax problems ................

Leo Sario and Cecilia Wang, Counterexamples in the biharmonic classification of Riemannian 2-manifolds...

Saharon Shelah, The Hanf number of omitting complete types ...

Richard Staum, The algebra of bounded continuous functions into a

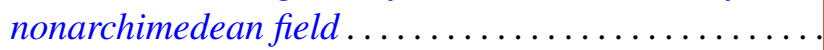

James DeWitt Stein, Some aspects of automatic continuity ..

Tommy Kay Teague, On the Engel margin

John Griggs Thompson, Nonsolvable finite groups all of whose local subgroups are solvable, $V \ldots \ldots \ldots \ldots \ldots \ldots \ldots \ldots$

Kung-Wei Yang, Isomorphisms of group extensions 